\title{
Perspective of pharmaceutical practice in adrenal insufficiency: An integrative
}

\section{review}

\author{
Perspectiva da prática farmacêutica na insuficiência adrenal: Uma revisão integrativa \\ Perspectiva de la práctica farmacéutica en insuficiencia suprarrenal: Una revisión integradora
}

Received: 05/17/2021 | Reviewed: 05/27/2021 | Accept: 05/30/2021 | Published: 06/13/2021

Juliana Denicoli Silvestre Caetano
ORCID: https://orcid.org/0000-0002-5148-8718
Fluminense Federal University, Brazil
E-mail: julianadenicoli@id.uff.br
Selma Rodrigues de Castilho
ORCID: https://orcid.org/0000-0003-0272-4777
Fluminense Federal University, Brazil
E-mail: selmarc@id.uff.br
Vania dos Santos
ORCID: https://orcid.org/0000-0001-8197-8294
University of Ribeirão Preto, Brazil
E-mail: vasantos@ usp.br

\begin{abstract}
An integrating review of the literature about the perspectives of the pharmaceutical practices in Adrenal Insufficiency (AI) was carried out. Researches were done on the LILACS database, Medline (Pubmed), and Scientific Electronic Library OnLine-SCIELO. Articles published between January 2007 and February 2021, written in Portuguese, English, and Spanish, were included. A total of 43 articles were selected to compose the review. A great deal of the studies considers patient education fundamental for the treatment and AI control. Among the education measures found in these studies, which can subside the service routines are: guidelines on the precipitating factors, signs and disease symptoms, dose adjustment, drug interaction, and condition identification cards. Relevant interventions of clinic management reported hospital discharge plans, management of AI acute and chronic phases, home care management, and routine outpatient follow-up. For an effective self-care support system, patient-centered assistance must be the core of the health care standards model. The review establishes that the AI patient follow-up must be performed regularly by a multidisciplinary team. It also allowed the identification of health measures that a pharmacist integrated with the healthcare team should perform.
\end{abstract}

Keywords: Adrenal insufficiency; Pharmaceutical services; Pharmacology.

\section{Resumo}

Realizou-se uma revisão integrativa da literatura sobre as perspectivas da prática farmacêutica na insuficiência adrenal (IA). Foram realizadas buscas nas bases de dados LILACS, Medline (Pubmed) e ScientificElectronic Library OnLineSCIELO. Foram incluídos artigos nos idiomas português, inglês e espanhol, publicados no período de Janeiro de 2007 a Fevereiro de 2021. Foram selecionados 43 artigos para compor a revisão. Grande parte dos estudos considera a educação do paciente fundamental para o sucesso do tratamento e controle da IA. Dentre as ações de educação encontradas nos estudos e que podem subsidiar rotinas de serviços estão: orientações sobre fatores precipitantes, sinais e sintomas da doença, ajuste de dose, interação medicamentosa e uso de cartão de identificação da condição. As intervenções relevantes de manejo clínico reportaram plano de alta hospitalar, gerenciamento das fases agudas e crônicas da IA, bem como o gerenciamento domiciliar e acompanhamento ambulatorial de rotina. Para um suporte de autocuidado efetivo o cuidado centrado no paciente deve ser o cerne do modelo de prestação de cuidados de saúde. A revisão deixa claro que o acompanhamento a pacientes com IA deve ser realizado de forma contínua por equipe multidisciplinar e permitiu identificar ações em saúde passíveis de realização por um profissional farmacêutico integrado à equipe de saúde.

Palavras-chave: Insuficiência adrenal; Assistência farmacêutica; Farmacologia.

\section{Resumen}

Se realizó una revisión integradora de la literatura sobre las perspectivas de la práctica farmacéutica en la insuficiencia suprarrenal (IA). Las búsquedas se realizaron en las bases de datos LILACS, Medline (Pubmed) y ScientificElectronic Library OnLine-SCIELO. Se incluyeron artículos en portugués, inglés y español, publicados desde enero de 2007 hasta febrero de 2021. Se seleccionaron 43 artículos para componer la revisión. La mayoría de los estudios consideran 
que la educación del paciente es esencial para el éxito del tratamiento y control de la IA. Entre las acciones educativas encontradas en los estudios que pueden apoyar las rutinas del servicio se encuentran: orientación sobre factores precipitantes, signos y síntomas de la enfermedad, ajuste de dosis, interacción farmacológica y uso de la tarjeta de identificación de la condición. Las intervenciones de manejo clínico relevantes informaron el plan de alta hospitalaria, el manejo de las fases aguda y crónica de la IA, así como el manejo domiciliario y el seguimiento ambulatorio de rutina. Para un apoyo de autocuidado eficaz, la atención centrada en el paciente debe estar en el centro del modelo de prestación de atención médica. La revisión deja claro que el seguimiento de los pacientes con IA debe ser realizado de forma continua por un equipo multidisciplinar y permitió la identificación de acciones de salud que podrían ser realizadas por un profesional farmacéutico integrado con el equipo de salud.

Palabras clave: Insuficiencia suprarrenal; Cuidado farmacêutico; Farmacología.

\section{Introduction}

The adrenal glands secrete three classes of hormones: glucocorticoids, mineralocorticoids e androgens (Dineen, Thompson \& Sherlock, 2019). Adrenal Insufficiency (AI) occurs when the adrenal glands produce an insufficient quantity of one or more of these hormone classes (Nieman, 2021).

AI is a potentially fatal disease, divided into three types: Primary Adrenal Insufficiency (PAI), or Addison's Disease, Secondary Adrenal Insufficiency (SAI), and Tertiary Adrenal insufficiency (TAI). Early identification of AI may be difficult, as the symptoms are usually non-specific, making the diagnosis process harder. However, with proper treatment and additional precautions, patients affected by this disease may expect to lead an active everyday life (Silva, et al., 2004; Ekman, et al., 2014; Nieman, 2021).

PAI, first described by Thomas Addison in 1855, can have a genetic or an acquired cause. It is defined by the incapacity of the adrenal cortex to produce sufficient quantities of glucocorticoids and/or mineralocorticoids. It is characterized by low production of cortisol and a high amount of ACTH (adrenocorticotropic hormone). The cortisol deficiency results from feedback in the ACTH production stimulation, elevating its plasma levels (Castro \& Elias, 2003; Bornstein, et al., 2016).

PAI is a severe condition, potentially lethal, due to the central role of these hormones in the maintenance of the body energy, the control of salt levels, and fluid homeostasis, being characterized by signs and symptoms such as weakness, exhaustion, anorexia, darkening of the skin, weight loss, nausea, and vomiting. Craving for salt is the only specific symptom of this syndrome, and the frequent delay in the diagnosis may result in a life-threatening acute crisis (Silva, et al., 2004; Bornstein, et al., 2016; Husebye, et al.,2014).

SAI occurs due to pituitary failure in secreting the primary hormone which stimulates the adrenal cortex, the ACTH. The low production of ACTH may be caused by pituitary or hypothalamic deficiency; in this case, there is a reduction in the hormone's secretion that releases the corticotropin $(\mathrm{CRH})$ by the hypothalamus, characterizing TAI. Both SAI and TAI symptoms are similar to the PAI, with few differences, such as the lower frequency in the appearance of signals, darkening of the skin, dehydration, and gastrointestinal symptoms. The hypoglycemic symptoms are more common, including perspiration, anxiety, restlessness, nausea, among others (Nieman, 2021).

The Adrenal Crisis (AC) is related to the acute phase of the disease, which is the most serious, as it is life-threatening and commonly feared. A 2019 publication revealed a prevalence of 6.6-8.3 AC/100 patient-years, with mortality of 0.5/100 patient-years, mainly due to gastrointestinal and other infectious diseases (Alexandraki \& Grossman, 2019). The most usual symptoms are systemic crash, dehydration, abdominal symptoms, and unbalance of sodium and potassium levels in the body. The adrenal crisis generally occurs after an infection, trauma, or another component that represents stress for the organism, situations in which there is a greater necessity for producing the hormones. This condition requires emergency medical treatment, with extra corticoid input and correction of the unbalance of salt in the system (Silva, 2004; Nieman, 2021). A 2020 study showed that more than $50 \%$ of patients with adrenal crisis do not have a previous diagnosis of adrenal insufficiency. Thus education about the diagnosis and extra steroid dose information is a crucial part of managing an adrenal crisis (Elshimy, 
Alghoula \& Jeong, 2021)

Many authors point out that a clinical assessment and medical evaluation, integrated with other disciplines, is very important for the efficient habilitation of the disease carriers (Dineen, Thompson \& Sherlock, 2019; Elshimy \& Alghoula \& Jeong, 2021; Huecker, Bhutta \& Dominique, 2021; Munir, Quintanilla Rodriguez \& Waseem, 2021). Patients with AI, at chronic phase, require a follow-up which includes regular drug monitoring, to avoid under-treatment. It could lead to clinical deterioration of patient health and adrenal crisis (AC), as well as hypercortisolism. It can cause the appearance of a myriad of adverse effects, for example, arterial hypertension, an increase in the glucose blood screenings and deceleration of growth, and also decrease in the quality of life (Calero \& Padilla, 2014; Husebye, et al., 2016).

In the multidisciplinary context, the proper management of the disease will provide the tools and necessary knowledge to empower the patients for the practice of self-care (CFF, 2016). Considering the importance of the pharmacist's participation in the care of patients with chronic diseases, the objective of this study is to discuss possible pharmaceutical actions in the management of Adrenal Insufficiency.

\section{Methodology}

An integrating review of the literature (Pereira et a., 2018) about the perspectives of the pharmaceutical practices in Adrenal Insufficiency (AI) was carried out. Researches were done on the LILACS database, Medline (Pubmed), and Scientific Electronic Library OnLine-SCIELO. Articles published between January 2007 and February 2021, written in Portuguese, English, and Spanish, were included. There was no gender or age restriction in the population. The study selection was carried out by two reviewers, with a third one present for the disagreement cases.

Studies that approached AI focusing on etiology, precipitating factors, symptoms, management of acute and chronic phases of the disease, adverse effects in the treatment, prevention strategies, and education were included.

Database research used the following descriptors: Insufficiency, Adrenal Gland Hypofunction, Pharmaceutical Services, Preventive Health Services, Health Education, Patient Care Team, Continuity of Patient Care, Patient Safety. Descriptors in Portuguese, English, and Spanish languages and their synonyms were applied to the search.

Considering that the initial search did not mention articles that specifically dealt with the pharmaceutical professional, the pharmacist was regarded as part of the multidisciplinary team for this research. Due to heterogeneity, the selected articles were grouped in two categories: (i) Studies of guidelines and education of the patients, and (ii) Studies of clinical management of the disease. The division considered the characteristics of the actions approached in the studies, and it had the goal to facilitate the presentation, and subsequently, the comprehension of the results.

Microsoft Excel report sheets, one in each study group, were the data extraction instrument.

\section{Results}

The comprehensive database research resulted in 352 articles. With the withdrawal of duplicated articles, there were 325 articles left. In the first screening process, reading titles and summaries, 216 articles that were not related to the AI were removed.

In the second triage, a complete reading of the text, 109 articles were selected. Forty-two of them were chosen to compose the integrating review. There was also the inclusion of one piece, with relevant content for the research, selected from the reading process of the searched articles, not by a direct result of this search, but chosen as a similar topic, adding up to a total of 43 pieces (Figure 1). 
Figure 1. Flowchart of the database search.

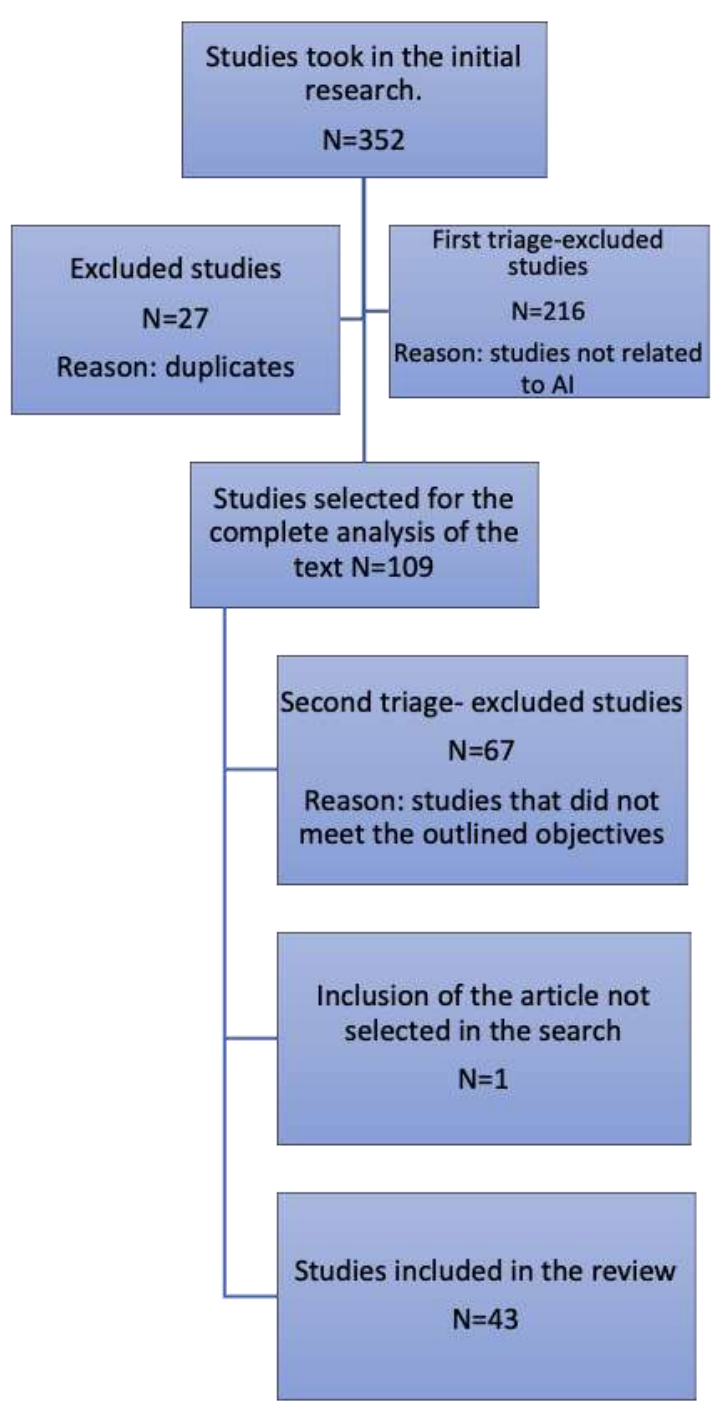

Source: Authors.

Chart 1 presents the systematization and analysis of the data resulting from the education and clinical management studies' characteristics. It summarizes the recommendations identified in each study. From the total of studies of the education category, 94,7\% affirmed that the patient's education is fundamental for preventing the adrenal crisis and the success of the treatment and the control of AI. Recommendations and guidelines of preventive measures, like emergency kits and condition identification cards, or medical bracelets, were mentioned in $66,7 \%$ of the articles in the category of clinical management of the disease. In the education category, those actions were mentioned by $89,4 \%$ of the groups. 
Chart 1. Synthesis of the characteristics of the studies in education and clinical management of AI, N=43.

\begin{tabular}{|c|c|c|}
\hline Authors & $\begin{array}{l}\text { Purpose of the Study/ } \\
\text { Interventions }\end{array}$ & Recommendations \\
\hline $\begin{array}{l}\text { Aguayo, A. M., et } \\
\text { al. (2007) }\end{array}$ & $\begin{array}{l}\text { Presentation of clinical } \\
\text { cases of patients with AI. }\end{array}$ & $\begin{array}{l}\text { a) Monitoring the clinical symptoms and blood pressure, } \\
\text { plasmatic renin activity, and electrolytes during long-term } \\
\text { replacement therapy. }\end{array}$ \\
\hline $\begin{array}{l}\text { Jones, D. A.; } \\
\text { MirasA. \& Tringha } \\
\text { M J. R. (2008) }\end{array}$ & $\begin{array}{l}\text { Review Article of clinical } \\
\text { practice. }\end{array}$ & $\begin{array}{l}\text { a) Monitoring of glucocorticoid and mineralocorticoid; } \\
\text { b) Education of patients and families is essential. }\end{array}$ \\
\hline $\begin{array}{l}\text { Alves, C.; Robazzi, } \\
\text { T. C. V. \& } \\
\text { Mendonça, } \\
\text { (2008) }\end{array}$ & $\begin{array}{l}\text { Security review of the } \\
\text { suspension of the corticoid } \\
\text { therapy in patients with } \\
\text { prolonged treatments. }\end{array}$ & $\begin{array}{l}\text { a) Carry out dose adjustments in stress situations; b) } \\
\text { Whenever possible, the corticoid intermediary or prolonged } \\
\text { dose action must be taken in only one dose in the morning; c) } \\
\text { Every patient that received prolonged therapy or elevated doses } \\
\text { must be considered at risk of developing AI until a year after the } \\
\text { suspension of the corticoid therapy. }\end{array}$ \\
\hline $\begin{array}{l}\text { Molimard, M., et } \\
\text { al. (2008) }\end{array}$ & $\begin{array}{l}\text { Investigation of } \mathrm{AI} \\
\text { predominance caused by } \\
\text { the use of inhalation } \\
\text { corticoids. }\end{array}$ & $\begin{array}{l}\text { a) Orientation of patients with AIS about an adrenal } \\
\text { crisis, occurrence conditions, clinical symptoms, and } \\
\text { prevention; b) Monitoring of the adrenal function in case it is } \\
\text { necessary to use inhalation corticoids in high doses. }\end{array}$ \\
\hline $\begin{array}{l}\text { Harsch, I., et } \\
\text { al.(2010) }\end{array}$ & $\begin{array}{l}\text { Analysis of the knowledge } \\
\text { of support groups. }\end{array}$ & $\begin{array}{l}\text { a) Complement individual advising with printed material } \\
\text { (books, leaflets, guides); b) Carry out motivational interviews to } \\
\text { promote adherence to the treatment. }\end{array}$ \\
\hline $\begin{array}{ll}\text { O`Connel, } & \text { S. } \\
\text { Siafarikas, } & \text { A. } \\
(2010) & \end{array}$ & Review Article. & $\begin{array}{l}\text { a) The medical intervention should not be delayed by the } \\
\text { wait for a diagnosis; b) Encouraging the use of condition } \\
\text { identification card; c) The patient must have IM hydrocortisone } \\
\text { preparation for emergencies. }\end{array}$ \\
\hline $\begin{array}{l}\text { Hittle, K.; Hsieh, S } \\
\& \quad \text { Sheeran, P. } \\
(2010)\end{array}$ & $\begin{array}{l}\text { Review Article with a case } \\
\text { report. }\end{array}$ & $\begin{array}{l}\text { a) An endocrinologist and a professional at primary care } \\
\text { must follow AI patients and a professional; } \\
\text { b) The adherence to the treatment is essential for good } \\
\text { results in the long term. }\end{array}$ \\
\hline $\begin{array}{l}\text { Martinez, A., et al., } \\
\text { (2010) }\end{array}$ & & $\begin{array}{l}\text { a) In an adrenal crisis, even in doubt, act fast, correcting } \\
\text { the glycemia, electrolytes and administrating hydrocortisone; b) } \\
\text { In case of stress, when there is oral intolerance, the IV must be } \\
\text { used. }\end{array}$ \\
\hline Reddy, P. (2011) & & $\begin{array}{l}\text { a) Treatment for patients with suspicion of the adrenal } \\
\text { crisis must be immediately started with saline solution and IV } \\
\text { glucocorticoids; b) Education of family and patients for the } \\
\text { management in stress situations. }\end{array}$ \\
\hline $\begin{array}{l}\text { Franco, L., et al., } \\
(2012)\end{array}$ & & $\begin{array}{l}\text { a) Dose adjustment in case of disease acuteness; b) The } \\
\text { sick patients must carry an identification card of the disease so } \\
\text { that the treatment in these unbalance situations is quick and } \\
\text { appropriate. }\end{array}$ \\
\hline $\begin{array}{lrr}\text { Napier, } & \text { C. } & \text { \& } \\
\text { Pearce, } & \text { S. } & \text { H.S. } \\
(2012) & & \end{array}$ & & $\begin{array}{l}\text { a) Continuous Education of patients and healthcare } \\
\text { professional is essential to minimize the risks of adrenal crisis; } \\
\text { b) Continuous outpatient follow-up for the tracking of } \\
\text { simultaneous autoimmune disorders. }\end{array}$ \\
\hline $\begin{array}{lrr}\text { Moloney, } & \text { S. } \\
\text { Dowling, } & & \text { M. } \\
(2012) & & \end{array}$ & $\begin{array}{l}\text { Development of AI } \\
\text { identification cards and } \\
\text { discharge planning. }\end{array}$ & $\begin{array}{l}\text { a) Parental education; b) The patient must carry a } \\
\text { condition identification card; c) The continued education must } \\
\text { be carried out according to age/child development. }\end{array}$ \\
\hline $\begin{array}{l}\text { Repping-Wuts, H. J } \\
\text { W. J., et al. (2013) }\end{array}$ & $\begin{array}{r}\text { Educational } \\
\text { meetings in groups. }\end{array}$ & $\begin{array}{l}\text { a) Educational meetings in groups to enhance self- } \\
\text { management; b) Carrying out pieces of training for emergency } \\
\text { administration of a glucocorticoid. }\end{array}$ \\
\hline $\begin{array}{l}\text { Bjornadottir, S., et } \\
\text { al., (2013) }\end{array}$ & $\begin{array}{l}\text { Description of patterns of } \\
\text { prescription of drugs. } \\
\text { Study of cut. }\end{array}$ & $\begin{array}{l}\text { b) Among women, it is crucial to evaluate androgen } \\
\text { insufficiency, as they can be affected by premature ovarian } \\
\text { insufficiency. In many cases, they can precede or follow } \\
\text { diagnosis; b) Observe the overdose of a glucocorticoid to } \\
\text { prevent hypertension and obesity. }\end{array}$ \\
\hline
\end{tabular}




\begin{tabular}{|c|c|c|}
\hline Authors & $\begin{array}{l}\text { Purpose of the Study/ } \\
\text { Interventions }\end{array}$ & Recommendations \\
\hline $\begin{array}{l}\text { Aguirre, M. A., et } \\
\text { al., (2013) }\end{array}$ & $\begin{array}{l}\text { Development of the } \\
\text { information protocol about } \\
\text { diagnosis and the } \\
\text { management of AI. }\end{array}$ & $\begin{array}{l}\text { a) In patients whose hypertension does not show any } \\
\text { improvement with the hydrocortisone, the administration of } \\
\text { glucocorticoid of prolonged action can extend a better coverage } \\
\text { during the night with correction of the clinical condition; b) In } \\
\text { surgeries, the inducer of anesthetic, etomidate must be avoided } \\
\text { as it inhibits the synthesis of corticoids. }\end{array}$ \\
\hline $\begin{array}{l}\text { Palacio, A. V., } \\
\text { González, V. B. \& } \\
\text { Maya, G. C. (2013) }\end{array}$ & ReviewArticle. & $\begin{array}{l}\text { a) Directions for the suspension of the corticoid therapy: } \\
\text { reduction of the dose between } 10 \% \text { and } 20 \% \text {, within } 3 \text { to } 7 \text { days, } \\
\text { changing to an only dose at a fixed time, in alternated days, } \\
\text { until reaching } 50 \% \text { to } 100 \% \text { of the physiologic doses and, at this } \\
\text { point, replace the corticoid in use to hydrocortisone and have an } \\
\text { axle assessment; }\end{array}$ \\
\hline $\begin{array}{l}\text { Dinsen, S., et al., } \\
\text { (2013) }\end{array}$ & Review article. & $\begin{array}{l}\text { a) If the patient does not need treatment with } \\
\text { glucocorticoid for an underlying disease, change the respective } \\
\text { glucocorticoid for the hydrocortisone and initiate reduction;b) In } \\
\text { case of clinical deterioration, the decline must be interrupted, } \\
\text { and the doctor contacted. }\end{array}$ \\
\hline $\begin{array}{l}\text { Rushworth, R. L., } \\
\& \text { Torpy, D. J. } \\
(2014)\end{array}$ & $\begin{array}{l}\text { Analysis of adrenal crisis } \\
\text { incidence, morbidity, and } \\
\text { mortality patterns of } \\
\text { patients with AI. }\end{array}$ & $\begin{array}{l}\text { a) It is crucial to educate patients to follow the guidelines } \\
\text { for "the disease days"; b) A lower limit to institute antibiotic } \\
\text { therapy is justified in older patients with AI due to the } \\
\text { significance of a bacterial infection at the beginning of an AC. }\end{array}$ \\
\hline Vilar, M. N. (2014) & Review Article. & $\begin{array}{l}\text { a) Chronic treatment: use of the half-life corticoid } \\
\text { (prednisone or dexamethasone) avoids changes in the } \\
\text { concentrations during the day; b) Follow the overdosing of } \\
\text { corticoids due to the risk of osteoporosis and decrease of bone } \\
\text { density. }\end{array}$ \\
\hline $\begin{array}{l}\text { Kluguer, N., et al., } \\
\text { (2014) }\end{array}$ & $\begin{array}{l}\text { Evaluate the quality of life } \\
\text { of patients with Addison's } \\
\text { disease. }\end{array}$ & $\begin{array}{l}\text { a) Evaluate the excess in corticoid therapy: patients with } \\
\text { doses above } 30 \mathrm{mg} \text { of hydrocortisone demonstrate commitment } \\
\text { with the quality of life in comparison to those with a lower daily } \\
\text { dose; b) Research concomitant autoimmune diseases. }\end{array}$ \\
\hline $\begin{array}{l}\text { Quinkler, M., et al. } \\
\text { (2014) }\end{array}$ & $\begin{array}{l}\text { Development of a } \\
\text { European identification } \\
\text { card for AI patients. }\end{array}$ & $\begin{array}{l}\text { a) the card must mention the clinical need in the pre- } \\
\text { hospital and hospital contexts. b) Promote training for self- } \\
\text { injecting to improve the autonomy of the patients. }\end{array}$ \\
\hline $\begin{array}{l}\text { Calero, T. M. G., \& } \\
\text { Padilha, K. G. } \\
\text { (2014) }\end{array}$ & Review article. & $\begin{array}{l}\text { a) The medical knowledge must be reinforced by the } \\
\text { support of other areas; b) Promote education for parents and } \\
\text { friends, aiming at proper practical measures, preventing } \\
\text { unfavorable outcomes. }\end{array}$ \\
\hline $\begin{array}{l}\text { Kauw, D., et al. } \\
(2015)\end{array}$ & $\begin{array}{l}\text { Quality analysis of the } \\
\text { contribution of online } \\
\text { forums to patient care. }\end{array}$ & $\begin{array}{l}\text { a) Assistance standard model must be centered in the } \\
\text { patient; b) Use of the condition identification card; c) } \\
\text { Education in group meetings or in other educational programs to } \\
\text { favor self-management. }\end{array}$ \\
\hline $\begin{array}{l}\text { Inder, W. J., } \\
\text { Meyer, C., \& Hunt, } \\
\text { P. J. (2015) }\end{array}$ & Case study. & $\begin{array}{l}\text { a)In cardiac insufficiency, the ECA inhibitors, } \\
\text { antagonists of the AII receptors and of the aldosterone, } \\
\text { indicated a decrease in mortality; b) In hypertension, the } \\
\text { diuretics, due to effects in the volume of plasma and excretion } \\
\text { of potassium. }\end{array}$ \\
\hline $\begin{array}{lr}\text { Moloney, } & \text { S., } \\
\text { Murphy, N., } \quad \& \\
\text { Colin, J. (2015) }\end{array}$ & Review Article. & $\begin{array}{l}\text { a) Planning of hospital discharge and homecare } \\
\text { management; b) Monitoring growth speed in children. }\end{array}$ \\
\hline $\begin{array}{l}\text { Puar, T. H. K., et } \\
\text { al. (2016) }\end{array}$ & Review Article. & $\begin{array}{l}\text { a) The treatment of the adrenal crisis must happen } \\
\text { immediately and should not be delayed for diagnosis purposes; } \\
\text { b) Doctors must be familiarized with dose adjustment during } \\
\text { stressful situations or diseases. }\end{array}$ \\
\hline $\begin{array}{l}\text { Fares, A. B., \& } \\
\text { Santos, } \\
(2016)\end{array}$ & Review Article. & $\begin{array}{l}\text { a) Carry a condition identification card; b) Increase the } \\
\text { glucocorticoid } 2 \text { or } 3 \text { times in periods of stress for the system. It } \\
\text { is necessary to offer the injection in periods of crisis. }\end{array}$ \\
\hline
\end{tabular}




\begin{tabular}{|c|c|c|}
\hline Authors & $\begin{array}{l}\text { Purpose of the Study/ } \\
\text { Interventions }\end{array}$ & Recommendations \\
\hline $\begin{array}{l}\text { Van Eck, J. P., et } \\
\text { al., (2016) }\end{array}$ & $\begin{array}{l}\text { Evaluate self-management } \\
\text { of patients with AI. (Use } \\
\text { of a survey) }\end{array}$ & $\begin{array}{l}\text { a) Actions regarding the management of patients: } \\
\text { adherence to repository treatment, recognize symptoms of acute } \\
\text { adrenal insufficiency and necessities of dose adaptation and } \\
\text { anticipated measures; b) Written information to support oral } \\
\text { education; }\end{array}$ \\
\hline $\begin{array}{l}\text { Odenwald, B., et } \\
\text { al., (2016) }\end{array}$ & $\begin{array}{l}\text { Evaluation of } \mathrm{AC} \text { in } \\
\text { Children up to six (use of } \\
\text { surveys and medical } \\
\text { reports). }\end{array}$ & $\begin{array}{l}\text { a) To avoid acute hypoglycemia in children: alteration of } \\
\text { the schedule of the administration of hydrocortisone to } 3 \text { to } 4 \\
\text { times a day, introducing one dose at night or during the night; b) } \\
\text { Use of condition identification cards. }\end{array}$ \\
\hline $\begin{array}{l}\text { Kampmeyer, D., et } \\
\text { al. (2016) }\end{array}$ & $\begin{array}{l}\text { Evaluation of the medical } \\
\text { knowledge in AI. }\end{array}$ & $\begin{array}{l}\text { a)Improvement of professional knowledge must be } \\
\text { focused on typical situations found in clinical practice; } \\
\text { b)Education of the patient. }\end{array}$ \\
\hline $\begin{array}{l}\text { Shepherd, L. M., et } \\
\text { al. (2017) }\end{array}$ & $\begin{array}{l}\text { Evaluation of the AI } \\
\text { patients' knowledge about } \\
\text { the disease. }\end{array}$ & $\begin{array}{l}\text { a)It is relevant that family, professionals, and volunteers } \\
\text { acquire knowledge concerning the patient's condition, the } \\
\text { replacement therapy, and the dose adjustment during } \\
\text { occurrences. }\end{array}$ \\
\hline $\begin{array}{l}\text { Bowden, S. A., \& } \\
\text { Henry, R. (2018) }\end{array}$ & $\begin{array}{l}\text { AI diagnosis and treatment } \\
\text { review. }\end{array}$ & $\begin{array}{l}\text { a) Education of patients and caregivers about } \\
\text { maintenance medications and stress nutrition for illnesses; b) } \\
\text { Instruction for administering injectable glucocorticoids for cases } \\
\text { where oral administration is impossible; c) Use of medical alert } \\
\text { identification and medical emergency information card. }\end{array}$ \\
\hline $\begin{array}{l}\text { Alexandraki, k. L., } \\
\& \text { Grossman, A. } \\
(2018)\end{array}$ & $\begin{array}{l}\text { Clinical recognition of } \\
\text { Adrenal Insufficiency. }\end{array}$ & $\begin{array}{l}\text { a) Patient and family education; b) Instructions on daily } \\
\text { dose in case of intercurrent febrile illness, accident, or severe } \\
\text { mental stress c) injection kit for emergency use and use } \\
\text { instructions ; d) Use of "medical alert" bracelet or necklace and } \\
\text { Emergency Medical Information Card. }\end{array}$ \\
\hline $\begin{array}{l}\text { Alexandraki, k. L., } \\
\& \text { Grossman, A. } \\
(2019)\end{array}$ & $\begin{array}{l}\text { Review of the management } \\
\text { of hypopituitarism. }\end{array}$ & $\begin{array}{l}\text { a) Patient education about "sick-day-rules" b) } \\
\text { Monitoring pregnant women with AI to document clinical } \\
\text { symptoms and signs of over-and under-replacement by } \\
\text { glucocorticoids. }\end{array}$ \\
\hline $\begin{array}{l}\text { Dineen, R., } \\
\text { Thompson, C. J., \& } \\
\text { Sherlock M. (2019) }\end{array}$ & $\begin{array}{l}\text { Adrenal crisis prevention } \\
\text { and } \\
\text { strategies. }\end{array}$ & $\begin{array}{l}\text { a) Patient education to prevent adrenal crises; b) } \\
\text { Additional dose of hydrocortisone in situations of } \\
\text { psychological stress or prolonged physical exercise; c) Use of a } \\
\text { steroid emergency card, medical alert wristbands /necklaces. }\end{array}$ \\
\hline $\begin{array}{l}\text { Oprea, A., et al., } \\
(2019)\end{array}$ & $\begin{array}{l}\text { Description of } \\
\text { glucocorticoid replacement } \\
\text { therapy in chronic AI. }\end{array}$ & $\begin{array}{l}\text { a) Patient education; b) Instruction on dose adaptation } \\
\text { during stressful events; c) Use of emergency card and kit for } \\
\text { parenteral glucocorticoid self-administration. }\end{array}$ \\
\hline $\begin{array}{l}\text { Bowden, S. A., et } \\
\text { al., (2019) }\end{array}$ & $\begin{array}{l}\text { Review Article of clinical } \\
\text { practice. }\end{array}$ & $\begin{array}{l}\text { a) Withdrawal of prolonged glucocorticoid therapy } \\
\text { should be made gradually; b) Provide teaching on AI, as well as } \\
\text { the dose of stress; c) Use of emergency steroid card. }\end{array}$ \\
\hline $\begin{array}{l}\text { Elshimy, } \quad \text { G., } \\
\text { Alghoula, F., \& } \\
\text { Jeong, J. M. (2020) }\end{array}$ & $\begin{array}{l}\text { Continuing } \\
\text { Activity. }\end{array}$ & $\begin{array}{l}\text { a) Following education about the "Sick days rule," the } \\
\text { doctor and the pharmacist should carry out stress dose, the } \\
\text { importance of wearing medical alert bracelets or necklaces and } \\
\text { emergency kit; b) Education on the adverse effects of } \\
\text { corticosteroids. }\end{array}$ \\
\hline $\begin{array}{l}\text { Rathbun, K. M., } \\
\text { Nguyen, M., \& } \\
\text { Singhal, M. (2020) }\end{array}$ & $\begin{array}{l}\text { Continuing } \\
\text { Activity. }\end{array}$ & $\begin{array}{l}\text { a) Individualized care plans; b) Educating the patient in } \\
\text { the event of acute illness; c) Use of bracelet or identity card; d) } \\
\text { The pharmacist has to educate the patient on medication } \\
\text { compliance to prevent a recurrence. }\end{array}$ \\
\hline $\begin{array}{l}\text { Miller, B. S., et al., } \\
(2020)\end{array}$ & $\begin{array}{l}\text { Raise awareness and guide } \\
\text { emergency management of } \\
\text { AI. }\end{array}$ & $\begin{array}{l}\text { a) Provide an Adrenal Insufficiency Action Plan to } \\
\text { known AI patients and their families, including maintenance of } \\
\text { hydrocortisone dose, stress dose for hydrocortisone (both oral } \\
\text { and intramuscular/intravenous); b) Medical alert identification. }\end{array}$ \\
\hline $\begin{array}{lr}\text { Huecker, } & \text { M. } \\
\text { Bhutta, B. } \\
\text { Dominique, } & \text { E. }\end{array}$ & $\begin{array}{l}\text { Continuing } \\
\text { Activity. }\end{array}$ & $\begin{array}{l}\text { a) Education about illness and stress dose; b) Use of } \\
\text { medical alert bracelet/necklace, an emergency medical } \\
\text { information card; d) Management performed by an }\end{array}$ \\
\hline
\end{tabular}




\begin{tabular}{|l|l|l|}
\hline Authors & $\begin{array}{l}\text { Purpose of the Study/ } \\
\text { Interventions }\end{array}$ & Recommendations \\
\hline$(2021)$ & & $\begin{array}{l}\text { interprofessional team composed of an endocrinologist, } \\
\text { radiologist, an infectologist, intensivist, intensive care nurse, } \\
\text { and pharmacist. }\end{array}$ \\
\hline $\begin{array}{l}\text { Munir, S., } \\
\begin{array}{l}\text { Rodriguez, R. B. } \\
\text { S., \& Wassem, M. } \\
(2021)\end{array}\end{array}$ & $\begin{array}{l}\text { a) Education on management, monitoring, and } \\
\text { Activity. }\end{array}$ & $\begin{array}{l}\text { compliance with the treatment plan; b) Have an emergency } \\
\text { medical alert bracelet; c) Patient management and education } \\
\text { must involve an interprofessional team (doctors, nurses, and } \\
\text { pharmacists). }\end{array}$ \\
\hline
\end{tabular}

Source: Authors.

The aspects studied in the patient's education include activities that can subsidize the organization, implementation, healthcare service routines, support conduct towards the user, and maximize the insertion of the pharmacist in the care of patients with AI (Chart 2). Precipitating factors of crises were identified, the need for guidance on adjustments to the dose of cortisone, as well as on the procedure to be adopted in the event of a missed dose, drug interactions and long-term adverse effects are some of the aspects pointed out.

Chart 2: Educational actions approached in the studies.

\begin{tabular}{|c|c|}
\hline $\begin{array}{l}\text { Aspects } \\
\text { discussed in } \\
\text { the } \\
\text { actions }\end{array}$ & Characteristics \\
\hline $\begin{array}{l}\text { Precipitating factors in } \\
\text { the adrenal crisis }\end{array}$ & $\begin{array}{l}\text { One of the principal causes of AC is failure to increase the replacement dose of } \\
\text { glucocorticoids in able time in patients undergoing stressful episodes (for example, } \\
\text { infections and surgeries); other factors include the non-adherence to therapy; intense, } \\
\text { extended physical activity, as well as infections, surgeries or some concomitant diseases as } \\
\text { hypothyroidism; abrupt suspension of prolonged treatment with corticoids, in therapeutic } \\
\text { doses, split doses, nocturnal doses, daily doses, long-term action corticoids and systemic } \\
\text { usage; maintenance doses, one-time doses, morning doses, alternating doses, short-term } \\
\text { action corticoids, topical and non-topical are the ones which offer fewer risks. }\end{array}$ \\
\hline $\begin{array}{l}\text { Adaptation in the } \\
\text { dosage of cortisone }\end{array}$ & $\begin{array}{l}\text { The dosage of the administration of the corticoid and the course of action will vary } \\
\text { in the face of exceptional situations, such as intense exercises, psychological stress, fever, } \\
\text { colds, infections, and diseases. Patients and caregivers must have their oral administration } \\
\text { strategies for these kinds of situations, with proper orientation to the necessity of another } \\
\text { form of administration of the drug, and search for medical assistance. }\end{array}$ \\
\hline Drug Interaction & $\begin{array}{l}\text { Some drugs, like rifampicin, phenytoin, and barbiturates, can accelerate the } \\
\text { metabolism of steroids and decrease their concentration, making them a risk factor for the } \\
\text { AC. Ketoconazole, metopirone, etomidate, aminoglutemine, and suramin can inhibit } \\
\text { cortisol synthesis. It is necessary to adjust the dose in case of treatment with some of these } \\
\text { drugs. Interaction also occurs with inhalation corticoids with ritonavir and itraconazole, } \\
\text { which increase the corticoid concentration. }\end{array}$ \\
\hline Skipping one dose & $\begin{array}{l}\text { Suppose the patient reports not having taken the last dose of glucocorticoid of the day } \\
\text { under an intermittent regime. In that case, it must be considered that this dose is, in fact, } \\
\text { necessary, and recommending the patient to take this dose as soon as possible is advisable. } \\
\text { However, if the next dose is close, the skipped dose must be left aside. }\end{array}$ \\
\hline Emergency kit & $\begin{array}{l}\text { Patients must be taught when and how to use the emergency kit containing rectal, } \\
\text { muscular, and IV hydrocortisone at home (in situations of imminent crisis with the } \\
\text { presence of vomiting or diarrhea). Provide a leaflet explaining the proper use of } \\
\text { hydrocortisone. }\end{array}$ \\
\hline $\begin{array}{l}\text { Condition } \\
\text { Identification Card or } \\
\text { Bracelet }\end{array}$ & $\begin{array}{l}\text { Carry a card or bracelet with proper identification helps to minimize the risks for } \\
\text { people in therapy with steroids. The card must contain personal data, such as name, } \\
\text { address, and birth date; contact details of close relatives and hospitals; drug regimen; } \\
\text { details of management for the disease days; oral, rectal, and intramuscular dosage for the } \\
\text { disease episode, lesions, or another stress in the system, and guidelines for the employees }\end{array}$ \\
\hline
\end{tabular}




\begin{tabular}{|l|l|}
\hline $\begin{array}{l}\text { Aspects discussed in } \\
\text { the } \\
\text { actions }\end{array}$ & Characteristics \\
\hline $\begin{array}{l}\text { Guidelines for the } \\
\text { disease days }\end{array}$ & $\begin{array}{l}\text { Patients and their caregivers need to follow the rules to adjust the corticoid dosage, } \\
\text { which will determine how to behave and what to do in case of an intercurrent event, such } \\
\text { as fever, infection, or other stressful situations. These typical rules are essential to avoid an } \\
\text { adrenal crisis with risk to life: the glucocorticoid dosage is tripled during three days, or } \\
\text { during a light disease, after this period, the usual dose can be reestablished, in case of } \\
\text { vomit and diarrhea, when the oral medication cannot be taken or absorbed, it is necessary } \\
\text { to seek medical attention for parental therapy. }\end{array}$ \\
\hline $\begin{array}{l}\text { Possible adverse effects } \\
\text { in long-term } \\
\text { treatment }\end{array}$ & $\begin{array}{l}\text { They are related to preparation, schedule, dose, duration, drug intake and } \\
\text { administration strategy, age, genre, and base disease. Weight gain, osteoporosis, and } \\
\text { vascular disease, diabetes, and hypertension are possible occurrences. Glycemic } \\
\text { monitoring is recommended, as well as the blood pressure, with an anti-hypertensive } \\
\text { recommendation if necessary. Follow growth, and give orientation, if pertinent, about the } \\
\text { supplementation of calcium. The guidelines about the adverse effects of the glucocorticoid } \\
\text { treatment will contribute to therapy adherence. }\end{array}$ \\
\hline $\begin{array}{l}\text { Development of the } \\
\text { management of the } \\
\text { disease }\end{array}$ & $\begin{array}{l}\text { Patients need to keep informed to become independent and develop empowerment } \\
\text { and individual capacity to deal with daily care and make proper decisions in intercurrent } \\
\text { events. }\end{array}$ \\
\hline
\end{tabular}
Source: Authors.

Clinical management of the disease in the selected articles involved actions performed by multidisciplinary teams, such as treatment management activities, patient follow-up, and clinical interventions. Those aspects can contribute to the participation of integrated service from all healthcare professionals, including the pharmacist, in the AI patients care (Chart 3). It is important to emphasize the continuous aspect of the proposed actions, involving actions both in the hospital environment and in monitoring and guidance for self-care both in daily situations and in the acute phase.

Chart 3. Management of clinical actions approached in the studies.

\begin{tabular}{|l|l|}
\hline Interventions & PerformedActions \\
\hline DischargePlan & $\begin{array}{l}\text { - Provide specific verbal and written information about the condition; } \\
\text { - Maintain a slow-paced approach, allowing discussions and questions; } \\
\text { Provide a steroid therapy card, with explanations and written instructions about when and how } \\
\text { to adjust the doses of hydrocortisone, mainly if vomiting and diarrhea occur, and the right time } \\
\text { to take the child to the hospital or family doctor. } \\
\text { - Provide written instructions about the drugs and their storage, adding an emergency kit of } \\
\text { rectal/intramuscular hydrocortisone; } \\
\text {-Recommend medical alert bracelets, except for younger children; } \\
\text { - Provide relevant contacts of community agents and support groups; } \\
\text { - Check the outpatient consultation date and displacement problems so that it is possible to offer } \\
\text { home assistance to evaluate education and management of the condition; } \\
\text { - Program the phone call follow-up in the first week after hospital discharge. }\end{array}$ \\
\hline $\begin{array}{l}\text { Homecare } \\
\text { management }\end{array}$ & $\begin{array}{l}\text { - The instructions and written material must include dose regimen and how to administrate oral, } \\
\text { - Provide advice about safe storage of the drug and the importance of having an appropriate } \\
\text { supply of hydrocortisone, especially on vacation periods, holidays, and travels, to assure stress } \\
\text { doses; } \\
\text { - Provide verbal and written instructions for parents and caregivers about the condition and } \\
\text { adjacent cause; } \\
\text { - Emphasize the importance of early intervention; } \\
\text { - Provide clear instructions about the return for review consultations; } \\
\text { - The patient must carry a steroid card with information about the disease and medical alert } \\
\text { bracelets; } \\
\text { - Orientation about the dose adjustment in case of vaccines and dental procedures; } \\
\text { - Education about the signs and symptoms of hypoglycemia and home management; }\end{array}$ \\
\hline
\end{tabular}




\begin{tabular}{|l|l|}
\hline Interventions & PerformedActions \\
\hline & $\begin{array}{l}\text { - With older children, it is recommended to insert emergency contacts on the cell phone; } \\
\text { - Advice about trips that emphasize the necessity of bringing along the medication and } \\
\text { emergency packages in the carry-on luggage; } \\
\text { - Provide general information about washing hands, food hygiene, insect bites, and how to } \\
\text { avoid gastroenteritis; } \\
\text { - Emphasize that, when in doubt, it is better to give a stress dose than not doing so. }\end{array}$ \\
\hline $\begin{array}{l}\text { Management of } \\
\text { the acute phase of } \\
\text { the disease } \\
\text { (Adrenal Crisis) }\end{array}$ & $\begin{array}{l}\text { - Orientation about doubling or tripling the dose of oral maintenance in the event of a disease, } \\
\text { stress, or lesion, including fever; } \\
\text { - In case of vomiting, administrate intra-venal hydrocortisone or a suppository; } \\
\text { - In case of vomiting and diarrhea, administrate intramuscular hydrocortisone and find a } \\
\text { healthcare center; } \\
\text { - Consider the indicative signs of adrenal crisis, such as altered consciousness, circulatory } \\
\text { collapse, hypoglycemia, hyponatremia, hypercalcemia, apprehensions, usage history/suspension } \\
\text { of steroids, or any other clinical characteristics of Addison's disease. }\end{array}$ \\
\hline $\begin{array}{l}\text { Routine } \\
\text { Outpatient }\end{array}$ & $\begin{array}{l}\text { - Management review of the stress dose; } \\
\text { - Review of the rules for the disease days; } \\
\text { - Review of the emergency plan; } \\
\text { - Verify if the patient is wearing the condition medical alert bracelet; } \\
\text { - Verify if the emergency kit is available and within the expiration date; } \\
\text { - Consultation frequency: 4 to 6 months, and with younger children within shorter intervals; } \\
\text { - Registration of the auxology details; } \\
\text { - Verify the need for dose adjustments and new prescriptions in children at the growth stage; } \\
\text { - Review homecare management and medications; } \\
\text { - Monitoring of the blood pressure. }\end{array}$ \\
\hline
\end{tabular}

Source: Authors.

\section{Discussion}

Puar and contributors published a study emphasizing the AC as a deadly event, indicating that the control of AI and its potential life-threatening risks are still a challenge nowadays for the health care professionals (Puar, et al., 2016; Huecker, Bhutta \& Dominique, 2021; Munir, Quintanilla Rodriguez \& Waseem, 2021). Both the considerable mortality rates, morbid conditions, and the increasing frequency and fast pace in which the symptoms escalate leave a short period to act upon and fight this disease (Napier \& Pearce, 2012; Puar, et al., 2016; Odenwald, et al. 2016).

A study in 2021 indicated the delay in diagnosis as a factor for the increase in morbidity and mortality, besides the fact that the disease is better managed by an interprofessional health team, including endocrinologist, intensive care physician, infectious disease, and pharmacist (Munir, Quintanilla Rodriguez \& Waseem, 2021). Furthermore, the study of Dineen, Thompson, and Sherlock (2019) found that even in patients with treated AI, there is still morbidity and reduced life expectancy.

Calero and Padilha (2014), in a review about the encouragement of therapeutic education of chronic patients, highlights the importance of the support of all disciplines to strengthen the patient's education. They emphasize the role of education as treatment and reinforce that, in regards to chronic patients, it is not about the cure but about teaching self-care, a perspective ratified by other studies (Repping-Wuts, 2013; Van Eck, et al., 2016). The The role of interdisciplinary work is also highlighted by several studies (Elshimy, et al., 2020; Rathbun, et al.,2020; Munir, et al., 2021; Huecker, Bhutta \& Dominique, 2021). In this scenario, it is necessary to emphasize that the use of education strategies was prominent in $100 \%$ of the analyzed articles, showing that it is a current and decisive strategy in the control of the disease.

Patients with AI should receive education on management and monitoring, such as medication doses and compliance with the treatment plan; on the need to increase steroid replacement doses in stressful situations, such as fever, surgery, or stress; to have an emergency medical alert bracelet; self-care, including adequate sodium intake in the diet, monitoring weight 
and blood pressure (Bowden, Henry, 2018; Elshimy, Alghoula \& Jeong, 2020; Munir, Quintanilla Rodriguez \& Waseem, 2021).

The Ministry of Health in Brazil considers that, for emergency care in acute crisis, it is essential that every patient carries some identification (bracelet, necklace, or card) with the valuable information of their condition as well as their emergency contact numbers (Brasil, 2015).

One of the objectives of pharmaceutical care is the patient education, about the drugs and health problems, aiming at autonomy and supported self-care. The drug dispense system presents an opportunity for the pharmacist to offer guidelines that will bring benefits to the patients, such as the capacity for proper decision-making regarding the therapeutic regime of prescribed and non-prescribed drugs; understanding of the utility of drugs to maintain or promote well-being; comprehension of guidelines in case of possible side effects and drug interaction; an increase of knowledge; participation in the treatment of the disease and the management of self-care (CFF, 2008; Brasil, 2014).

Rathbun, Nguyen and Singhal (2020), Elshimy, Alghoula and Jeong (2020), Huecker, Bhutta and Dominique (2021), Munir, Quintanilha and Waseem (2021) specifically mention the monitoring of patients with AI by the pharmacist that should share the responsibility for patient education with doctors and nurses. Shepherd and contributors associated the adherence to the treatment to the proportional knowledge and comprehension of the patients (Shepherd, et al., 2017). Elshimy and colleagues (2020) show that the pharmacist must also guide patients on the adverse effects of treatment with corticosteroids.

Kampmeyer and contributors (2016) observed that, even though the result of the level of knowledge was considered good, only a low percentage of professionals could identify the situations in which the adjustment of therapy is required. On the other hand, Miller and collaborators (2020) indicate the possibility that patients become vulnerable to AC if they don't receive proper orientation about how and when acting in case of complications. Therefore, it is also necessary to invest in permanent education for the health care professionals, especially in primary care, to promote the qualification of the service at the frontline for patients with rare diseases, assuring adequate assistance to the family and patients. (Brasil, 2014).

Eight studies pointed out the delay in the diagnosis caused by the non-specific symptoms of the disease, the rare nature of this condition, and the low level of clinical suspicion. A study in Germany observed that $20 \%$ of the patients with AI presented symptoms of the disease for more than five years before being diagnosed, in an average of three consultations with different doctors, until the correct diagnosis, going through a lot of analysis and incorrect treatments before that. It happens because the decrease of hormone production by the adrenal gland occurs at a slow pace. The kidney function continues to deteriorate for years, and patients with sub-clinical symptoms can suddenly, in a moment of infection or stress in the system, such as surgeries, experience an AC (Jones, Miras \& Tringham, 2008; O'Connel \& Siafarikas, 2010; Bjornadottir, et al., 2013). Molimard and contributors (2008) described a case of a patient in the United Kingdom whose diagnosis occurred only three months before his death. This case emphasizes the role of the multidisciplinary team, either by permanent education or information support.

Adrenal crises are avoidable events, but remain a real and present danger for patients with AI. As in many countries, there is a proper availability of health care, and the objective is to eliminate mortality by AC (Puar, et al., 2016). In this sense, it is likely that the pharmacist, through his knowledge background and experience in the service area, may be able to contribute to security and quality of life to the patients with AI, promoting the good use of drugs, using practices as hosting, anamnesis and care plan implementation; identifying possible drug interactions in the therapy plan, maintaining a therapeutic follow-up, encouraging education about health and well-being, to develop autonomy and responsibilities of these patients, contributing for the decrease of AC episodes (CFF, 2016).

Kluguer and colleagues (2014) showed a negative impact on the quality of life and increased mortality, even among 
patients in treatment. This outcome can be explained by excessive corticoid doses used in substitution treatments, resulting in adverse side effects, by the presence of comorbidities associated with AI, demographic and socio-economic factors, and by the need for a health specialization follow-up. A study in Sweden found similar results, demonstrating that the general perception of health and vitality was low in all subgroups of AI patients, even though it was more expressive in those with simultaneous Type 1 Diabetes. The restrictions in quality of life have been higher with the feminine genre and high doses of corticoids. In this same study, affective disorders, irritability, somatic excitement, and reduced functional activity were reported, verified by the restriction in the working capacity and percentage of disability benefits (Bensing, et al., 2016). A 2018 publication reported reduced quality of life through detailed questionnaires on daily habits, work patterns, general energy sensations, mental concentration, daytime sleepiness, and power outages. (Alexandraki \& Grossmam, 2018).

One of the most emphasized issues, particularly in the most recent articles, is developing the self-management of the disease to improve patients' autonomy, as well as empowering them to care for their health and take action faster if necessary (Quinkler, et al., 2014; Moloney, Murphyn \& Colin, 2015; Odenwald, et al., 2016; Dineen, Thompson \& Sherlock, 2019). Van Eck and his colleagues (2016) verified that improper self-management during infectious diseases might significantly impact the high numbers of premature deaths in patients with AI.

According to Rushwort and Torpy (2014), self-management is the cornerstone of adrenal substitute therapy. The clinical pharmacist can offer support to patients and their families regarding self-care through education and counseling, strengthening their autonomy, knowledge, and adherence to treatment (CFF, 2013). Dineen, Thompson and Sherlock, in 2019, pointed out similar results, wherein a self-management investigation of patients with AI, in education group programs, for six months, obtained significantly positive results about behaviors regarding preventive safety measures in different situations.

Patients treated with corticoids are at risk of several drug interactions and adverse effects. Reports about meaningful interactions involving drugs with barbiturate, anticonvulsant, and antimicrobial rifampicin, will accelerate the metabolism of the corticoids, decreasing their concentration. Other studies pointed out that medications like fluconazole, ketoconazole, etomidate, among others that inhibit the synthesis of the endogenous cortisol, may lead patients with AI to a clinical picture of AC (Napier \& Pearce, 2012; Puar, et al., 2016; Alexandraki \& Grossman, 2018).

The side effects reported in the studies are correlated with the overtreatment, like obesity, hypertension, loss of glucose tolerance, and osteoporosis, and to the sub-treatment, like exhaustion, moodiness, and imminent crisis (Miller, et al., 2020). The patient needs to be continuously followed up, control the body weight, blood pressure, and glucose screenings, adjust the corticoid dose when necessary, and monitor the comorbidities (Kampmeyer, et al., 2016).

Moloney and Dowling's (2012) refer to a programmed phone call follow-up, conducted by an endocrinal nurse within the first week after the hospital discharge, to certify home self-management. A call center service destined explicitly for the follow-up of patients with chronic diseases is already a reality in some countries and is predicted by the directions for the proper care of people with chronic diseases in the health network in Brazil. Besides, it is an opportunity to trace the patient after the hospital discharge, evaluating the access to consultations, exams, medications, and the continuation of the health care, among other actions (Brasil, 2013).

At the moment of hospital discharge, it is necessary to predict possible occurrences concerning medication. Alterations in the drug treatment may occur as mistaken interpretations resulting from the inappropriate or less understandable drug prescriptions, divergence in therapies between hospitalization periods and hospital releases, problems with adherence to the treatment, and adverse effects. These factors can significantly affect the security and well-being of the patient and increase urgent calls and re-hospitalizations (Marques \& Romano-Lieber, 2014). Therefore, it is reasonable to consider that the pharmacist inserted in the multidisciplinary team can also act in the process of discharging and monitoring pharmacotherapy. 
The guidelines for full-time care to patients with rare diseases in the SUS (Sistema Único de Saúde - Unified Health System in Brazil), like AI, recommend that patient care must be carried out preferably by a multidisciplinary team. The interdisciplinarity should allow joined discussions, better comprehension of the condition, and continuing care (Brasil, 2014).

Thus, the pharmacist's clinical practice must integrate the healthcare teamwork practice and overcome interprofessional barriers to assure clinical results. The integrated approach is crucial for the utmost effectiveness and minimum risks in therapies (Araújo, et al., 2017).

However, as the main limitation of this review was the low number of publications specifically related to the performance of the pharmaceutical professional, further studies on the subject are still needed. This deficiency of information in still more critical in Brazil, resulting in the difficulty of obtaining a precise scenario of the pharmaceutical care in AI and identifying shortcomings and necessities for improvement in the assistance provided to these patients in the country.

\section{Conclusion}

This review enabled tracing a general panorama of the AI and identifying actions concerning the well-being of patients, which are likely to be put in practice by a pharmaceutical professional integrated into the healthcare team. It also demonstrates that a multidisciplinary team must continuously carry out the follow-up of patients with AI and that the outcome of regular education of the patient is still sub-optimal, revealing a necessity of a strategic course of action in education.

For adequate support in self-care, patient-centered assistance must be the core of the standard model for healthcare services. Patients with AI demand a replacement treatment of corticoids throughout their lives, with the need of adjusting the dose in situations of stress, and appropriate management of the disease will provide tools and the necessary knowledge to empower the patient in the practice of self-care

The results suggest the opportunity for the development of new studies that assess the results of the insertion of the pharmacist in the multidisciplinary team for monitoring patients with AI, including the analysis of the cost-effectiveness of this insertion.

\section{Conflict of interests Statement}

The authors state there is no conflict of interests. The study involved no financing or subsiding, neither a scholarship grant.

\section{References}

Aguirre, Miguel A, Luna, Magda, Reyes, Yubriangel, Gómez-Pérez, Roald, \& Benítez, Isabel. (2013). Diagnóstico y Manejo de la Insuficiencia Adrenal. Revista Venezolana de Endocrinología y Metabolismo, 11(3), 157-167. http://ve.scielo.org/scielo.php?script=sci_arttext\&pid=S1690$31102013000300007 \& \operatorname{lng}=\mathrm{es} \& \operatorname{lng}=\mathrm{es}$

Alexandraki K. I. \& Grossman A. (2019). Management of Hypopituitarism. J Clin Med., 8(12), 2153. doi:10.3390/jcm8122153.

Alves, C., Robazzi, T. C. V. \& Mendonça, M. (2008). Retirada da corticoterapia: recomendações para a prática clínica. Jornal de Pediatria, 84(3), 192-202. https://doi.org/10.2223/JPED.1773.

Bensing, S., Hulting, A., Husebye, E. S., Kämpe, O., \& Løvås, K. (2016). MANAGEMENT OF ENDOCRINE DISEASE: Epidemiology, quality of life and complications of primary adrenal insufficiency: a review, European Journal of Endocrinology, 175(3), R107-R116. https://eje.bioscientifica.com/view/journals/eje/175/3/R107.xml

Björnsdottir S., Sundström A., Ludvigsson J.F., Blomqvist P., Kämpe O. \& Bensing S. (2013). Drug prescription patterns in patients with Addison's disease: a Swedish population-based cohort study. J Clin Endocrinol Metab, 98(5), 2009-2018. doi: 10.1210/jc.2012-3561.

Bornstein, S. R., Allolio, B., Arlt, W., Barthel, A., Don-Wauchope, A., Hammer, G. D., Husebye, E. S., Merke, D. P., Murad, M. H., Stratakis, C. A., \& Torpy, D. J. (2016). Diagnosis and Treatment of Primary Adrenal Insufficiency: An Endocrine Society Clinical Practice Guideline. The Journal of clinical endocrinology and metabolism, 101(2), 364-389. https://doi.org/10.1210/jc.2015-1710 
Bowden S. A., Connolly A. M., Kinnett K. \& Zeitler P. S. (2019). Management of Adrenal Insufficiency Risk After Long-term Systemic Glucocorticoid Therapy in Duchenne Muscular Dystrophy: Clinical Practice Recommendations. J Neuromuscul Dis, 6(1), 31-41. doi:10.3233/JND-180346.

Brasil. Ministério da Saúde. Secretaria de Atenção à Saúde. (2013). Diretrizes para o cuidado das pessoas com doenças crônicas nas redes de atenção à saúde e nas linhas de cuidado prioritárias. Brasília: Ministério da Saúde.

Brasil. Ministério da Saúde. Secretaria de Ciência, Tecnologia e Insumos Estratégicos. (2014). Cuidado farmacêutico na atenção básica. Caderno 1: Serviços farmacêuticos na atenção básica à saúde. Brasília: Ministério da Saúde.

Brasil. Ministério da Saúde. Secretaria de Atenção à Saúde. (2014). Diretrizes para Atenção Integral às Pessoas com Doenças Raras no Sistema Único de Saúde - SUS Brasília: Ministério da Saúde.

Brasil. Ministério da saúde. (2015). Protocolo Clínico e Diretrizes Terapêuticas - Insuficiência Adrenal Primária (Doença de Addison). Portaria SAS/MS nº 1170, de 19 de novembro de 2015. Brasília: Ministério da Saude.

Broersen, L. H., Pereira, A. M., Jørgensen, J. O., \& Dekkers, O. M. (2015). Adrenal Insufficiency in Corticosteroids Use: Systematic Review and MetaAnalysis. The Journal of clinical endocrinology and metabolism, 100(6), 2171-2180. https://doi.org/10.1210/jc.2015-1218

González Calero, Teresa Margarita, \& González Padilla, Katrine. (2014). La educación terapéutica en pacientes con insuficiencia adrenal crónica. Revista Cubana de Endocrinología, 25(3), 231-236. http://scielo.sld.cu/scielo.php?script=sci_arttext\&pid=S1561-29532014000300011\&lng=es\&tlng=es

Castro, M. \& Elias, L. L. K. (2003). Insuficiência adrenal crônica e aguda. Medicina, 36(-4), 375-379. https://doi.org/10.11606/issn.2176-7262.v36i2/4p375379

Conselho Federal de Farmácia (CFF). (2008). O papel do farmacêutico comunitário no aconselhamento ao paciente. Boletim Farmacoterapêutico. Ano XIII. n. 4 e 5 Jul./out. Brasília: Conselho Federal de Farmácia.

Conselho Federal de Farmácia (CFF). (2013). Resolução nº 585 de 29 de agosto de 2013. Ementa: Regulamenta as atribuições clínicas do farmacêutico e dá outras providências. Brasília. https://www.cff.org.br/userfiles/file/resolucoes/585.pdf

Conselho Federal de Farmácia (CFF). (2016). Serviços farmacêuticos diretamente destinados ao paciente, à família e à comunidade: contextualização e arcabouço conceitual. Brasília: Conselho Federal de Farmácia.

Dineen, R., Thompson, C. J., \& Sherlock, M. (2019). Adrenal crisis: prevention and management in adult patients. Therapeutic advances in endocrinology and metabolism, 10, 2042018819848218. https://doi.org/10.1177/2042018819848218

Dinsen S., Baslund B., Klose M., Rasmussen A.K., Friis-Hansen L., Hilsted L. \& Feldt-Rasmussen U. (2013). Why glucocorticoid withdrawal may sometimes be as dangerous as the treatment itself. Eur J Intern Med, 24(8), 714-20. doi: 10.1016/j.ejim.2013.05.014.

Elshimy, G., Alghoula, F., \& Jeong, J. M. (2020). Adrenal Crisis. In StatPearls. StatPearls Publishing.

Ekman, B., Fitts, D., Marelli, C., Murray, R. D., Quinkler, M., \& Zelissen, P. M. (2014). European Adrenal Insufficiency Registry (EU-AIR): a comparative observational study of glucocorticoid replacement therapy. BMC endocrine disorders, 14, 40. Retrieved from https://doi.org/10.1186/1472-6823-14-40

Fares A. B. \& Dos Santos, R. A. (2016). Conduct protocol in emergency: Acute adrenal insufficiency. Rev. Assoc. Med. Bras., 62(8), 728-734. https://www.scielo.br/j/ramb/a/dvmW3zdbhSmFYQrjQvYD5NL/?lang=en 42302016000800728\&lng=en. https://doi.org/10.1590/1806-9282.62.08.728

Franco, L., Vieira, H., Vieira, P. \& Rabelo, I. (2012). Doença de Addison em idade pediátrica: um caso clínico. Nascer e Crescer, 21(2), 96-98. https://repositorio.chporto.pt/bitstream/10400.16/1333/1/06_CasosClinicos-1_21-2.indd.pdf

Harsch I.A., Schuller A., Hahn E. G. \& Hensen J. (2010). Cortisone replacement therapy in endocrine disorders - quality of self-care. J Eval Clin Pract., 16(3), 492-498. doi: 10.1111/j.1365-2753.2009.01149.

Hittle, K., Hsieh, S., \& Sheeran, P. (2010). Acute adrenal crisis masquerading as septic shock in a healthy young woman. Journal of pediatric health care : official publication of National Association of Pediatric Nurse Associates \& Practitioners, 24(1), 48-52. https://doi.org/10.1016/j.pedhc.2009.09.007

Huecker, M.R., Bhutta, B.S., Dominique, E. \& Bossuah, K. A. (2021). Insuficiência adrenal (nursing). Treasure Island (FL): StatPearls Publishing. Retrieved from https://fs53slaq3neykuquxervhfvj5a-adv7ofecxzh2qqi-www-ncbi-nlm-nih-gov.translate.goog/books/NBK568707/

Husebye, E. S., Allolio, B., Arlt, W., Badenhoop, K., Bensing, S., Betterle, C., Falorni, A., Gan, E. H., Hulting, A. L., Kasperlik-Zaluska, A., Kämpe, O., Løvås, K., Meyer, G., \& Pearce, S. H. (2014). Consensus statement on the diagnosis, treatment and follow-up of patients with primary adrenal insufficiency. Journal of internal medicine, 275(2), 104-115. https://doi.org/10.1111/joim.12162

Inder, W. J., Meyer, C., \& Hunt, P. J. (2015). Management of hypertension and heart failure in patients with Addison's disease. Clinical endocrinology, 82(6), 789-792. https://doi.org/10.1111/cen.12592

Jones, D. A., Miras, A., \& Tringham, J. R. (2008). Addison's disease: a diagnostic challenge. British journal of hospital medicine (London, England : 2005), 69(12), M192-M195. https://doi.org/10.12968/hmed.2008.69.sup12.31945

Kampmeyer, D., Lehnert, H., Moenig, H., Haas, C. S., \& Harbeck, B. (2016). A strong need for improving the education of physicians on glucocorticoid replacement treatment in adrenal insufficiency: An interdisciplinary and multicentre evaluation. European journal of internal medicine, 33, e13-e15. https://doi.org/10.1016/j.ejim.2016.04.006

Kluger, N., Matikainen, N., Sintonen, H., Ranki, A., Roine, R. P., \& Schalin-Jäntti, C. (2014). Impaired health-related quality of life in Addison's disease-impact of replacement therapy, comorbidities and socio-economic factors. Clinical endocrinology, 81(4), 511-518. https://doi.org/10.1111/cen.12484 
Marques, L. F. G. \& Romano-Lieber, N. S. (2014). Segurança do paciente no uso de medicamentos após a alta hospitalar: um estudo exploratório. Saúde e Sociedade [online], 23(4), 1431-1444. https://doi.org/10.1590/S0104-12902014000400025

Martínez, A., \& Heinrich, J. (2010). Emergencia pediátrica: insuficiencia suprarrenal aguda Pediatric emergency: adrenal insufficiency and adrenal crisis. Arch Argent Pediatr, 108(2), 167-170. doi: 10.1590/S0325-00752010000200018

Molimard, M., Girodet, P. O., Pollet, C., Fourrier-Réglat, A., Daveluy, A., Haramburu, F., Fayon, M., \& Tabarin, A. (2008). Inhaled corticosteroids and adrenal insufficiency: prevalence and clinical presentation. Drug safety, 31(9), 769-774. https://doi.org/10.2165/00002018-200831090-00005

Moloney, Sinéad, \& Dowling, Maura. (2012). Early intervention and management of adrenal insufficiency in children. Nursing Children and Young People, 24(7), 25-28. doi: 10.7748/ncyp.24.7.25.s23.

Moloney, S., Murphy, N., \& Collin, J. (2015). An overview of the nursing issues involved in caring for a child with adrenal insufficiency. Nursing children and young people, 27(7), 28-36. https://doi.org/10.7748/ncyp.27.7.28.e609

Munir, S., Quintanilla Rodriguez, B. S., \& Waseem, M. (2021). Addison Disease. In StatPearls. StatPearls Publishing.

Napier, C., \& Pearce, S. H. (2012). Autoimmune Addison's disease. Presse medicale (Paris, France: 1983), 41(12 P 2), e626-e635. https://doi.org/10.1016/j.lpm.2012.09.010

Nieman, L. K. (2021). Patient education: Adrenal insufficiency (Addison's disease) (Beyond the Basics). UpToDate. https://www.uptodate.com/contents/adrenal-insufficiency-addisons-disease-beyond-the-basics

O'Connell, S., \& Siafarikas, A. (2010). Addison disease - diagnosis and initial management. Australian family physician, 39(11), 834-837. https://pubmed.ncbi.nlm.nih.gov/21301655/

Odenwald, B., Nennstiel-Ratzel, U., Dörr, H., Schmidt, H., Wildner, M., \& Bonfig, W. (2016). Children with classic congenital adrenal hyperplasia experience salt loss and hypoglycemia: evaluation of adrenal crises during the first 6 years of life, European Journal of Endocrinology, 174(2), 177-186. https://eje.bioscientifica.com/view/journals/eje/174/2/177.xml

Oprea, A., Bonnet, N., Pollé, O., \& Lysy, P. A. (2019). Novel insights into glucocorticoid replacement therapy for pediatric and adult adrenal insufficiency. Therapeutic advances in endocrinology and metabolism, 10. https://doi.org/10.1177/2042018818821294

Palacio, A. V., González, B. V. \& Maya, G. C. (2013). Evaluation of hypothalamic-pituitary-adrenal axis function in children treated with steroids. Medicina \& Laboratorio, 19(03-04), 111-125 https://www.medigraphic.com/pdfs/medlab/myl-2013/myl133-4b.pdf

Pereira, A. S. et al. (2018). Metodologia da pesquisa cientifica. [free e-book]. Santa Maria: UAB/NTE/UFSM. https://repositorio.ufsm.br/bitstream/handle/1/15824/Lic_Computacao_Metodologia-Pesquisa-Cientifica.pdf?sequence.

Quinkler, M., Hahner, S., Johannsson, G., \& Stewart, P. M. (2014). Saving lives of patients with adrenal insufficiency: a pan-European initiative?. Clinical endocrinology, 80(3), 319-321. https://doi.org/10.1111/cen.12378

Puar, T. H., Stikkelbroeck, N. M., Smans, L. C., Zelissen, P. M., \& Hermus, A. R. (2016). Adrenal Crisis: Still a Deadly Event in the 21st Century. The American journal of medicine, 129(3), 339.e1-339.e3399. https://doi.org/10.1016/j.amjmed.2015.08.021

Reddy P. (2011). Clinical approach to adrenal insufficiency in hospitalised patients. International journal of clinical practice, 65(10), $1059-1066$. https://doi.org/10.1111/j.1742-1241.2011.02718.x

Repping-Wuts, H. J., Stikkelbroeck, N. M., Noordzij, A., Kerstens, M., \& Hermus, A. R. (2013). A glucocorticoid education group meeting: an effective strategy for improving self-management to prevent adrenal crisis. European journal of endocrinology, 169(1), 17-22. https://doi.org/10.1530/EJE-12-1094

Romanholi, D. J. P. C. \& Salgado, L. R. (2007). Exogenous Cushing's Syndromeand Glucocorticoid Withdrawal. ArqBrasEndocrinolMetab, 51(8),1280-1292. https://www.scielo.br/j/abem/a/KVfdmqMxwtGx5KFtkfVByKM/?lang=pt\&format=pdf

Rushworth, R. L., \& Torpy, D. J. (2014). A descriptive study of adrenal crises in adults with adrenal insufficiency: increased risk with age and in those with bacterial infections. BMC endocrine disorders, 14, 79. https://doi.org/10.1186/1472-6823-14-79

Shepherd, L. M., Tahrani, A. A., Inman, C., Arlt, W., \& Carrick-Sen, D. M. (2017). Exploration of knowledge and understanding in patients with primary adrenal insufficiency: A mixed methods study. BMC Endocrine Disorders, 17(1). https://doi.org/10.1186/s12902-017-0196-0

Silva, R. C., Castro, M. De, Kater, C. E., Cunha, A. A., Moraes, A. M., Alvarenga, D. B., Moreira, A. C. \& Elias, L. L. K. (2004). Insuficiência adrenal primária no adulto: 150 anos depois de Addison. ArqBrasEndocrinolMetab, 48 (5), https://www.scielo.br/j/abem/a/Z3HMNsNKKYLmBbZ3jrY9QTn/?lang=pt\#

Van Eck, J. P., Gobbens, R. J., Beukers, J., Geilvoet, W., van der Lely, A. J., \& Neggers, S. J. (2016). Much to be desired in self-management of patients with adrenal insufficiency. International journal of nursing practice, 22(1), 61-69. https://doi.org/10.1111/ijn.12368

Nuez Vilar, Marisela. (2014). Tratamiento sustitutivo en la insuficiencia suprarrenal crónica. Revista Cubana de Endocrinología, 25(3), 191-197. http://scielo.sld.cu/scielo.php?script=sci_arttext\&pid=S1561-29532014000300007\&lng=es\&tlng=es

Araújo, S. Q., Costa, K. S., Luiza, V. L., Lavras, C., Santana, E. A. \& Tavares, N. U. L. (2017). Organização dos serviços farmacêuticos no Sistema Único de Saúde em regiões de saúde. Ciência \& Saúde Coletiva, 22(4), 1181-1191. https://www.scielo.br/pdf/csc/v22n4/1413-8123-csc-22-04-1181.pdf

Rathbun, K. M., Nguyen, M., \& Singhal, M. (2020). Addisonian Crisis. In StatPearls. StatPearls Publishing.

Bowden, S. A., Henry, R. (2018). Pediatric Adrenal Insufficiency: Diagnosis, Management, and New Therapies. Int J Pediatr, 2018 (1), 1-8. doi: $10.1155 / 2018 / 1739831$ 
Research, Society and Development, v. 10, n. 7, e5610716197, 2021

(CC BY 4.0) | ISSN 2525-3409 | DOI: http://dx.doi.org/10.33448/rsd-v10i7.16197

Miller, B. S., Spencer, S. P., Geffner, M. E., Gourgari, E., Lahoti, A., Kamboj, M. K., Stanley, T. L., Uli, N. K., Wicklow, B. A., \& Sarafoglou, K. (2020). Emergency management of adrenal insufficiency in children: advocating for treatment options in outpatient and field settings. Journal of investigative medicine: the official publication of the American Federation for Clinical Research, 68(1), 16-25. https://doi.org/10.1136/jim-2019-000999

Alexandraki, K. I. \& Grossman, A. (2018). Adrenal Insufficiency. South Dartmouth (MA): MDText.com, Inc., South Dartmouth (MA). https://www.ncbi.nlm.nih.gov/books/NBK279087/?report=reader 